Elena G. Popkova ${ }^{1}$ Aidarbek Giyazov

Article info: Received 26.07.2020 Accepted 08.11.2020

UDC - 005.591.1:578.834 DOI - 10.24874/IJQR15.01-17

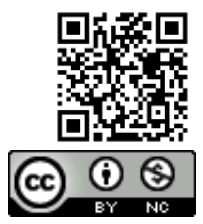

Quality has come to the foreground and become the characteristic of the healthcare system through which the approach to its

\section{INDUSTRIAL AND MANUFACTURING ENGINEERING IN FIGHT AGAINST THE VIRUS THREAT: PERSPECTIVES OF INCREASING QUALITY BASED ON DIGITALIZATION AND INDUSTRY 4.0}

Abstract: This paper is devoted to finding the importance of the factors of industrial and manufacturing engineering for fighting a virus threat and to substantiating the perspectives of increasing quality in the healthcare sphere of based on digitalization and Industry 4.0. The authors perform quantitative analysis of the influence of the factors of industrial and manufacturing engineering on quality of fight against the virus threat in comparison with the traditional factors. A qualitative treatment of the advantages of digitalization and Industry 4.0 with the help of industrial and manufacturing engineering for increasing the quality in fight against the virus threat is provided. The perspectives are modeled and recommendations are developed for increasing the quality of fight against the virus threat based on digitalization and Industry 4.0, with the help of industrial and manufacturing engineering. Originality and advantages of the research consist in the fact that successfulness of fight against the virus threat is treated not from the positions of resources (expenditures) but from the positions of results - quality. Due to this, the research contributes to formation of a concept of healthcare, which is oriented at the result and which guarantees high quality of medical services. Importance of the research is predetermined by determining the role of the technological factors (industrial and manufacturing engineering) in provision of quality of fighting the virus threat. Significance of the performed research for development of scientific knowledge consists in provision of substantiation and practical recommendations for applying a new - digital approach to fight against the virus threat.

Keywords: Industrial and Manufacturing Engineering; Fight against the virus threat; Healthcare; Quality; Quality Management; Digitalization; Industry 4.0.

\section{Introduction}

Corresponding author Elena G. Popkova

Email: elenapopkova@yahoo.com evaluation and management should be reconsidered. Due to the COVID-19 pandemic, the global system of healthcare faced a critically high burden. The criteria of analyzing the competitiveness of the national 
systems of healthcare have to be reconsidered. The traditional criteria include financial provision of healthcare, which determines sufficiency of the resource basis for executing its functions on provision of planned medical services (including drugs and other aspects of healthcare). Also, such traditional criteria as number of medical personnel and hospital beds are used - they characterize the production capacity and efficiency of the healthcare system.

In the conditions of urgent provision of medical services, instability of demand for them and quick increase of the burden on the healthcare system are observed; this does not allow for its timely adaptation (increase of efficiency and production capacities). The situation is difficult due to absence of a COVID-19 drug and vaccine against COVID19 with proved high effectiveness. The pandemic set new requirements to the healthcare system. People must have access to medical services and be able to count on their high quality, as, unlike planned medical services with conventionally fixed quality, the quality of urgent medical services could be different. For example, in case of COVID19 the presence of a highly-qualified doctor and a hospital bed does not guarantee quick recovery or prevention of a fatal outcome.

A perspective mechanism of quick adaptation of the healthcare system to the peak burden, which it faced in 2020, is digitalization, which is based on industrial and manufacturing engineering. In the conditions of the digital economy, there are three directions of increasing the quality of medical services. The first direction includes the use of Big data and AI for the healthcare purposes. These technologies will ensure collection of detailed statistics of morbidity and automatized analytics of the statistics. In particular, AI was used for selecting the perspective components of COVID-19 vaccines. Further development of "smart" healthcare envisages the search for mechanisms of restraint of infectious diseases - e.g., through analysis of social interactions, comparison of self-isolation variants, or substantiation of refusal from it.

The second direction consists in development of the system of online public services in the healthcare system. The online form of medical services allows for their partial automatization during AI's collecting the information from a patient, setting a preliminary diagnosis, and providing sample recommendations for treatment and for remote provision of medical services (information and consultation) by doctors, increasing their labor efficiency. Online public services also allow solving a lot of organizational issues in the healthcare sphere: online medical appointment booking, receipt of prescriptions, etc.

The third direction is hi-tech medical services - MedTech. Automatization, which is based on robotization, in healthcare allows creating leading equipment that is capable of increasing the labor efficiency of medical personnel and ensuring precision of laboratory research, diagnostics, manipulations, and creation of drugs, including vaccines. This could allow achieving better results in prevention and treatment of infectious diseases.

The originality and advantage of this research consists in the fact that successfulness of fight against the virus threat is treated not from the positions of resources (expenditures) but from the positions of results - quality. Due to this, the research contributes to formation of the concept of healthcare that is oriented at result and guarantees high quality of medical services. Importance of the research is predetermined by specifying the role of technological factors (industrial and manufacturing engineering) in provision of quality of fight against the virus threat.

The purpose of this research is to determine the role of the factors of industrial and manufacturing engineering for successful fighting against a virus threat and to substantiate the perspectives of increasing quality in the healthcare sphere based on digitalization and Industry 4.0. For achieving 
the set goal, the following tasks are solved:

- Quantitative analysis of the influence of the factors of industrial and manufacturing engineering on quality of fight against the virus threat in comparison with the traditional factors;

- Qualitative treatment of advantages of digitalization and Industry 4.0 with the help of industrial and manufacturing engineering for increasing quality of fight against the virus threat;

- Modeling the perspectives and developing recommendations for increasing quality of fight against the virus threat based on digitalization and Industry 4.0 with the help of industrial and manufacturing engineering.

\section{Literature Review}

In order to perform a literature overview, it is necessary to specify and determine the categorical tools of the research. Two aspects of functioning of the healthcare system are distinguished. $1^{\text {st }}$ aspect: provision of planned services and medical services to patients who pose a moderate threat to surrounding people (not threat of a pandemic). Quality of healthcare in this aspect is determined by sufficient financing of healthcare and accessibility of medical services (number of medical personnel and number of hospital beds).

$2^{\text {nd }}$ aspect: fight against the virus threat - i.e., urgent measures of healthcare, aimed at prevention or overcoming of infectious diseases pandemic with high danger in the form of complications and fatal cases. In this aspect, quality of healthcare is determined by reduction of morbidity rate and death rate from infectious diseases.

The important issues of fight against the virus threat are studied in the works of the modern authors. Da Costa et al. (2019) distinguish the factors that influence exchange of research data on zika virus and substantiate the theory of fighting this virus threat. Johanson and Madsen (2019) emphasize the controllability of virus threat and wide perspectives of its prevention with the help of management. Omar and Fen (2018) consider the recent development of SPR-spectroscopy as a potential method of diagnostics of Eprotein of dengue virus.

Plianbangchang (2018) offer a concept of healthcare with a special approach and increased attention to fighting the virus diseases. Platt et al. (2019) note the importance of society and information intermediaries' trust in the sphere of public healthcare and scientific research as the basis of fight against the virus threat. Larasanty et al. (2019) emphasize the necessity for orientation at patients' satisfaction with pharmaceutical services, provided in medical establishments of the primary and secondary levels in the system of medical insurance (by the example of Indonesia).

Candreva and Eger (2018) prove that results for health could be useful for specialists on the budget of public healthcare. Piroozi et al. (2019) show catastrophic expenditures for healthcare and their determinants in households with patients with gastrointestinal cancer (based on analysis of the data of a new reform of the healthcare system in Iran). Markham (2019) considers good functioning of a person, health, and strengthening of health as determinants of fight against the virus threat. Baaki et al. (2019) form conceptual framework for safe and sustainable health-care waste management (SSHCWM) in medical establishments for fight against the virus threat.

The conceptual and applied issues of provision of quality in the healthcare sphere have also been studied in detail. MacVane Phipps (2020) emphasizes the importance of initiatives in the sphere of public healthcare and other spheres, aimed at increase of quality in the healthcare sphere. Anaba and Abuosi (2018) offer a complex of scientific and methodological recommendations for evaluating and increasing the quality of medical services in clinics. 
Bahadori et al. (2018) evaluate the influence of accreditation on quality medical services, based on a view from the positions of nurses. Bäckström (2019) analyzes the role of quality management in healthcare as compared to its treatment by a manager and medical staff. Pronovost et al. (2018) outline the next (future, perspective) level of responsibility of the board of directors on quality of medical services. Bader and Ganguli (2019) perform an analysis of connection between economic growth, quality of environment, and healthcare in The Cooperation Council for the Arab States of the Gulf in 1980-2012.

Vijay (2014) notes the necessity for reducing and optimizing the duration of the cycle of patients release with the use of the six sigma approach. Thandapani et al. (2014) track the evolution of the medical studies register in developing countries (by the example of Malaysia). Doğu (2012) perform a monitoring of time between medical errors for improving the quality of medical aid. Tadić et al. (2009) offer a methodological approach to monitoring of therapy procedures with the help of AI methods, connected to achievement of high quality in the processes of medical services provision.

General issues of increasing the quality of goods and services due to application of the leading technologies and progressive capabilities of the digital economy and Industry 4.0 are studied in the work Popkova et al. (2020). Inshakova and Bogoviz (2020) offer the alternative methods of evaluating economic conflicts in the national positive and soft law. Alpidovskaya and Popkova (2019) perform a political and economic analysis of social systems' management.

Popkova (2017) outlines the economic and legal framework of the modern Russian society. Popkova and Sergi (2019) determine the contradiction of the digital economy, which consists in opposition of complexity, variability, flexibility, and rationality. Popkova and Sergi (2020) study human capital and AI in Industry 4.0 from the positions of convergence and divergence in social entrepreneurship in Russia. Sergi et al. (2019b) outline the perspectives of financial development of Central Asia and China through cooperation with Russia in the sphere of the leading technologies, which could allow for more effective quality management in healthcare.

Sergi et al. (2019a) define public-private partnership as a mechanism of financing of sustainable development. Popkova and Sergi (2018) show that Industry 4.0 and other innovations have large influence on Russia's socio-economic development. Sergi (2019) considers technologies, smart cities, and regional development in modern Russia. Sergi (2003) studies economic dynamics in countries with transitional economy by the example of four countries' governments, expansion of the EU, and the Brussels consensus. Ragulina (2019) substantiates the priorities of development of Industry 4.0 in modern economic systems with different progress in formation of the knowledge economy.

Stolyarov et al. (2020) determines new players and new logic of decision making in the digital reality of the modern economy. Popkova (2019) describes the preconditions of formation and development of Industry 4.0 in the knowledge economy. Popkova and Gulzat (2020a) and Popkova and Gulzat (2020b) study the essence of the fourth industrial revolution, transition to Industry 4.0 , and formation of the knowledge economy through the prism of various contradictions. Popkova and Zmiyak (2019) outline the priorities of digital personnel training for Industry 4.0 and show that in order to raise the quality of healthcare services it is necessary to use a competence-based approach to digital personnel training.

The experience and prospects of digitalization and improvement of the practices of fight against the virus threat based on capabilities of Industry 4.0 are studied in the existing publications. Young (2018) show the critical and interdisciplinary perspectives of formation 
and development of digital healthcare. Rubbio et al. (2019) show that digital medical technologies strengthen sustainable behavior of people in society. Nayak et al. (2019) prove the perspectives of applying digital technologies in medical insurance for consumers' social benefit in India. Andersen et al. (2019) outlines the necessity to use and barriers in the form of high cost and the digital (infrastructural) gap in online healthcare (by the example of modern Denmark).

Thus, the literature overview has shown that the theoretical foundations of studying the considered problem are already forms which allows for its elaboration. However, the gap analysis has shown that the scale, character, and essence of the influence of the factors of industrial \& manufacturing engineering on successfulness of fight against the virus threat are poorly studied and require further research. In addition to this, the perspectives of increasing the quality of fight against the virus threat based on digitalization and Industry 4.0 with the help of managing the factors of industrial \& manufacturing engineering have not been clearly determined and substantiated. Here we aim to fill these gaps.

\section{Materials and method}

In order to determine the perspectives of increasing the quality of fight against the virus threat based on digitalization and Industry 4.0 with the help of managing the factors of industrial and manufacturing engineering, we offer and verify a range of the following scientific hypotheses:

- Hypothesis $H_{l}$ : factors of industrial and manufacturing engineering positively influence the quality in fight against the virus threat, stimulating its increase (positive correlation);

- Hypothesis $\mathrm{H}_{2}$ : factors of industrial and manufacturing engineering largely determine the quality in fight against the virus threat (correlation - above 50\%);

- Hypothesis $\mathrm{H}_{3}$ : factors of industrial and manufacturing engineering determine quality in fight against the virus threat to a larger extern than traditional factors (correlation between quality of healthcare and the factors of industrial and manufacturing engineering is higher than with traditional factors);

- Hypothesis $\mathrm{H}_{4}$ : contribution of the factors of industrial and manufacturing engineering in increase of quality of healthcare services depends on the level of digitalization of an economic system, which determines the economic system's ability to successfully cope with a virus threat (large differences in correlation between countries with different digital competitiveness and different successfulness of fight against the virus threat).

In order to optimize the research and verify all offered hypotheses, the research objects are countries of two categories. The first category contains countries with the best results in fight against the virus threat in 2020 - i.e., with the best positions in the global ranking of countries' positions in the context of the COVID-2019 pandemic in 2020 dataset "Epidemics and pandemics: Big data for the scientific analytics of the dynamics of infectious diseases throughout the world and their consequences"). It should be noted that these countries are also the leaders in the IMD Digital Competitiveness Ranking.

The second category contains countries with the worst results in fight against the virus threat in 2020; these countries occupy peripheral positions in the Digital Competitiveness Ranking. The selected approach to classification of countries in this paper allows considering quality and digitalization of healthcare. Statistics of digital competitiveness and quality of healthcare in the selected countries are systematized and shown in Figure 1. 
Countries with the best results in fighting against the virus threat in 2020

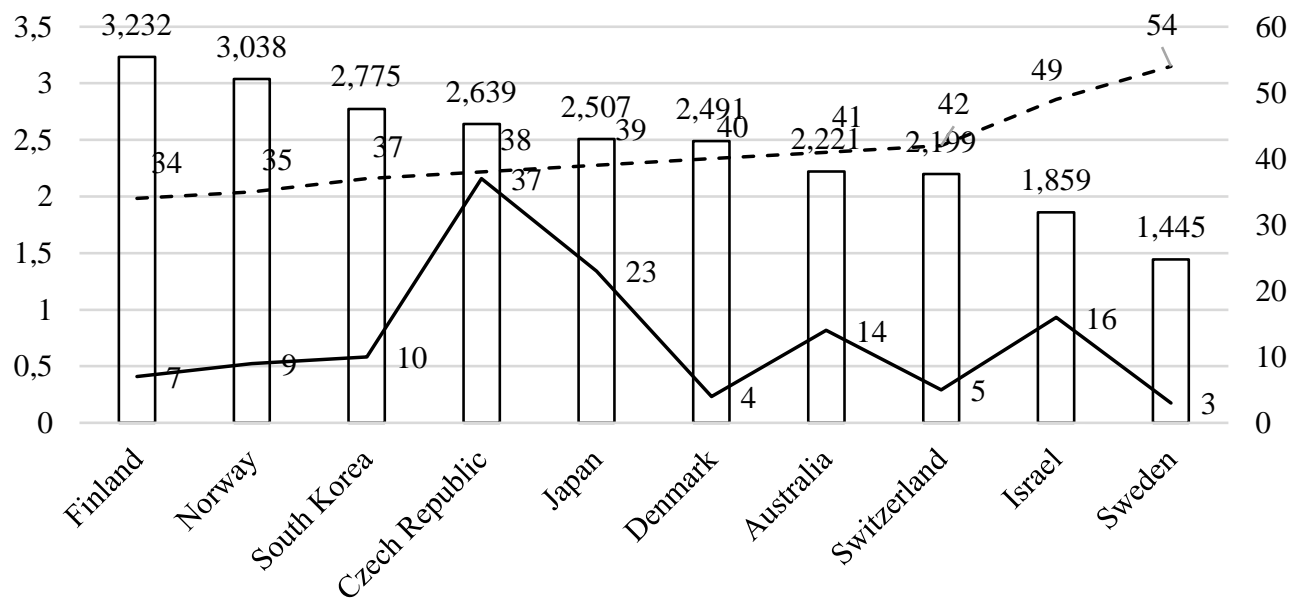

- - - Position in the global ranking

Position in the Digital Competitiveness Ranking

Countries with the worst results in fight against the virus threat in 2020

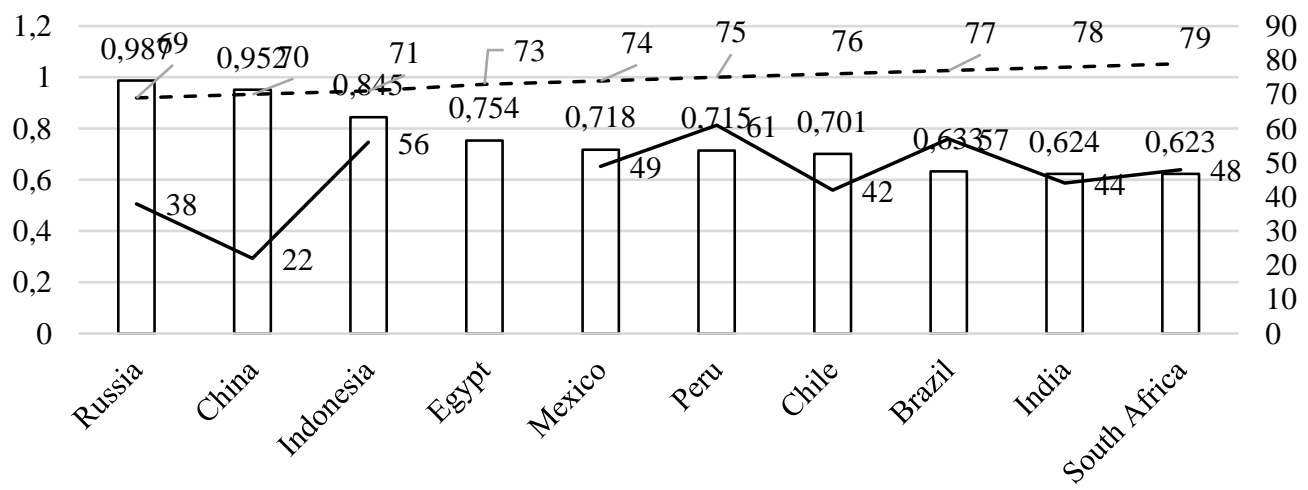

$\square$ Index of position during the COVID-19 pandemic

Figure 1. Statistics of digital competitiveness and quality of healthcare in countries of the distinguished categories in 2020

Source: compiled by the authors based on Institute of Scientific Communications (2020), IMD (2020)

As shown in Figure 1, in the first category Finland occupies the $34^{\text {th }}$ position in ranking of position during the COVID-19 pandemic (3.232 points) - i.e., it shows high quality of healthcare, as well as high level of digitalization ( $7^{\text {th }}$ position). For comparison, in the second category Russia occupies the $69^{\text {th }}$ position in the rankling of position during the COVID-19 pandemic (0.987 points) - i.e., it shows moderate quality of healthcare and moderate level of digitalization $\left(38^{\text {th }}\right.$ position). Therefore, the differences between countries of the distinguished categories are very vivid. 
The statistical framework of the research includes manifestations of quality in fight against the virus threat:

- infectious diseases mortality rate in 2016, \%;

- number of HIV cases in $2018, \%$ of population aged 15-49;

- tuberculosis morbidity rate per 100,000 people in 2018 ;

- number of COVID-19 cases;

- death rate from COVID-19, \%.

Secondly, traditionally accounted factors of quality in healthcare (with proved significance for planned medical services, but with uncertain influence on fight against the virus threat):

- healthcare expenditures in $2016, \%$ of GDP;

- number of medical personnel per 1,000 people (most recent data);
- number of hospital beds per 1,000 people (most recent data);

Thirdly, the factors of industrial and manufacturing engineering (determining the quality of healthcare based on digitalization and Industry 4.0 and potentially having a large role in fight against the virus threat):

- world robots distribution as a manifestation of use of Big data and AI for the healthcare purposes;

- use of Big data and analytics as a manifestation of hi-tech medical services (MedTech);

- e-government as a manifestation of online public services in the healthcare system;

The selected statistical data for countries of the first category are shown in Table 1 , for countries of the second category - in Table 2.

Table 1. Quality of healthcare and the traditional and industrial and manufacturing engineering factors that influence it in countries with the best results in fight against the virus threat in 2020

\begin{tabular}{|c|c|c|c|c|c|c|c|c|c|c|c|}
\hline \multirow[b]{2}{*}{ Country } & \multicolumn{5}{|c|}{$\begin{array}{c}\text { Manifestations of quality in fighting a } \\
\text { virus threat }\end{array}$} & \multicolumn{3}{|c|}{$\begin{array}{l}\text { Traditionally accounted } \\
\text { factors }\end{array}$} & \multicolumn{3}{|c|}{$\begin{array}{c}\text { Factors of industrial and } \\
\text { manufacturing } \\
\text { engineering }\end{array}$} \\
\hline & 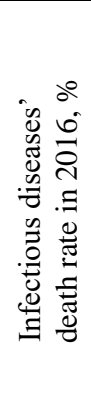 & 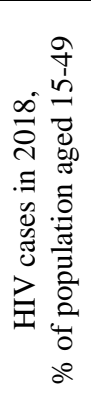 & 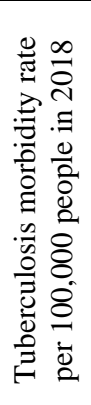 & 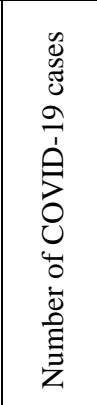 & 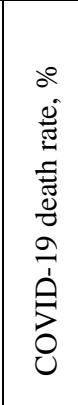 & 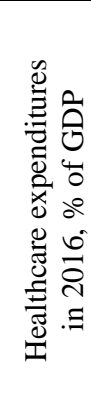 & 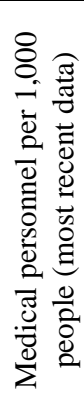 & 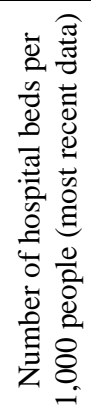 & 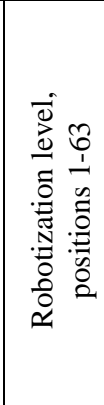 & 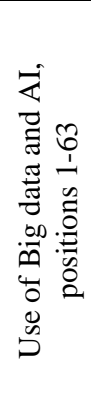 & 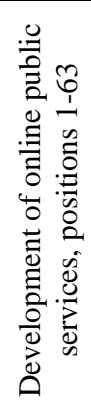 \\
\hline Finland & 93.2 & 0.1 & 4.7 & 7,117 & 4.581 & 9.21 & 3.8 & 4.4 & 33 & 24 & 6 \\
\hline Norway & 87.0 & 0.1 & 4.1 & 8,692 & 2.807 & 10.45 & 2.9 & 3.9 & 41 & 15 & 14 \\
\hline South Korea & 79.8 & $\mathrm{n} / \mathrm{a}$ & 66.0 & 12,257 & 2.284 & 7.60 & 2.4 & 11.5 & 3 & 40 & 3 \\
\hline \begin{tabular}{|c|} 
Czech \\
Republic \\
\end{tabular} & 89.9 & 0.1 & 5.4 & 10,176 & 3.272 & 7.23 & 4.1 & 6.5 & 16 & 36 & 45 \\
\hline Japan & 82.4 & 0.1 & 14.0 & 17,588 & 5.316 & 10.94 & 2.4 & 13.4 & 2 & 63 & 10 \\
\hline Denmark & 89.7 & 0.1 & 5.4 & 12,534 & 4.787 & 10.11 & 4.0 & 2.5 & 30 & 17 & 1 \\
\hline Australia & 89.5 & 0.1 & 6.6 & 7,391 & 1.380 & 9.21 & 3.7 & 3.8 & 29 & 28 & 2 \\
\hline Switzerland & 89.6 & $\mathrm{n} / \mathrm{a}$ & 6.4 & 31,200 & 6.269 & 12.35 & 4.3 & 4.7 & 27 & 29 & 15 \\
\hline \begin{tabular}{|l|} 
Israel \\
\end{tabular} & 85.8 & 0.2 & 4.0 & 19,894 & 1.523 & 7.41 & 4.6 & 3.1 & 39 & 3 & 27 \\
\hline Sweden & 89.9 & $\mathrm{n} / \mathrm{a}$ & 5.5 & 56,043 & 9.016 & 11.02 & 4.0 & 2.6 & 17 & 7 & 5 \\
\hline
\end{tabular}

$\mathrm{n} / \mathrm{a}$ - no data in the source

Source: compiled by the authors based on Institute of Scientific Communications (2020), IMD (2020) 
Table 2. Quality of healthcare and the traditional and industrial and manufacturing engineering factors that influence it in countries with the worst results in fight against the virus threat in 2020

\begin{tabular}{|c|c|c|c|c|c|c|c|c|c|c|c|}
\hline \multirow[b]{2}{*}{ Country } & \multicolumn{5}{|c|}{$\begin{array}{c}\text { Manifestations of quality in fighting } \\
\text { a virus threat }\end{array}$} & \multicolumn{3}{|c|}{$\begin{array}{l}\text { Traditionally accounted } \\
\text { factors }\end{array}$} & \multicolumn{3}{|c|}{$\begin{array}{l}\text { Factors of industrial and } \\
\text { manufacturing } \\
\text { engineering }\end{array}$} \\
\hline & 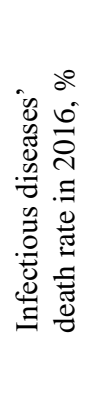 & 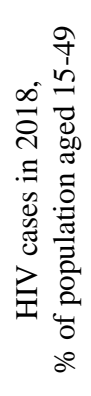 & 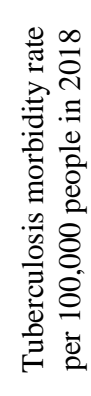 & 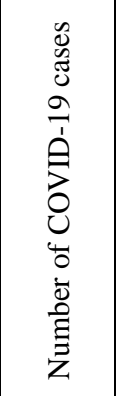 & 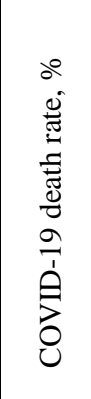 & 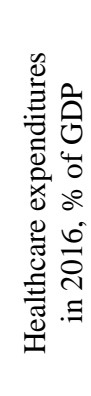 & 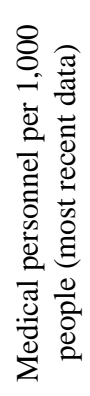 & 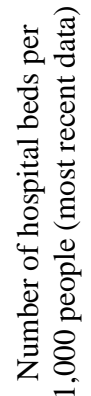 & 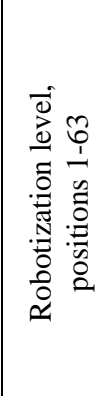 & 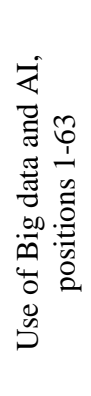 & 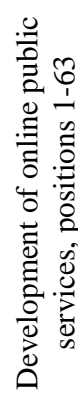 \\
\hline Russia & 87.4 & $\mathrm{n} / \mathrm{a}$ & 54.0 & 560.279 & 1.363 & 5.34 & 4.0 & 8.2 & 34 & 31 & 28 \\
\hline China & 89.3 & $\mathrm{n} / \mathrm{a}$ & 61.0 & 84.462 & 5.491 & 5.15 & 2.0 & 4.2 & 1 & 12 & 50 \\
\hline Indonesia & 73.3 & 0.4 & 316.0 & 42.762 & 5.470 & 2.99 & 0.4 & 1.2 & 25 & 8 & 61 \\
\hline Egypt & 84.1 & 0.1 & 12.0 & \begin{tabular}{|l|}
49.219 \\
\end{tabular} & 3.759 & 5.29 & 0.5 & 1.6 & $\mathrm{n} / \mathrm{a}$ & $\mathrm{n} / \mathrm{a}$ & $\mathrm{n} / \mathrm{a}$ \\
\hline Mexico & 79.9 & 0.2 & 23.0 & 159.793 & 11.940 & 5.52 & 2.4 & 1.5 & 11 & 56 & 49 \\
\hline Peru & 69.2 & 0.3 & 123.0 & \begin{tabular}{|l|}
240.908 \\
\end{tabular} & 3.012 & 5.00 & 1.3 & 1.6 & 54 & 59 & 55 \\
\hline Chile & 84.7 & 0.5 & 18.0 & 220.628 & 1.639 & 8.98 & 2.6 & 2.2 & 47 & 52 & 35 \\
\hline Brazil & 73.9 & 0.5 & 45.0 & 955.377 & 4.868 & 9.47 & 2.2 & 2.2 & 19 & 60 & 37 \\
\hline India & 62.7 & $\mathrm{n} / \mathrm{a}$ & 199.0 & 366.946 & 3.335 & 3.53 & 0.9 & 0.7 & 13 & 30 & 58 \\
\hline $\begin{array}{l}\text { South } \\
\text { Africa }\end{array}$ & 51.3 & 20.4 & 520.0 & 80,412 & 2.082 & 8.11 & 0.9 & 2.8 & 32 & 20 & 52 \\
\hline
\end{tabular}

$\mathrm{n} / \mathrm{a}$ - no data in the source.

Source: compiled by the authors based on Institute of Scientific Communications (2020), IMD (2020)

The research methodology consists of correlation analysis, which is used for determining the dependence (connection) of the manifestations of quality in fight against the virus threat on various factors - traditional factors and factors of industrial and manufacturing engineering. Comparative analysis is used for comparing correlation between quality in fight against the virus threat and different factors and for determining the differences in their significance for quality of healthcare. Also, the differences between the distinguished categories of countries are determined.

\section{Results}

\subsection{Quantitative analysis of influence of the factors of industrial and manufacturing engineering on quality of fight against the virus threat in comparison with the traditional factors}

For performing a quantitative analysis of influence of various factors on quality of fight against the virus threat based on the data from Table 1, the following results of correlation analysis of quality of healthcare with the traditional factors (Figure 2) and the factors of industrial and manufacturing engineering are received for countries of the first category (Figure 3). 


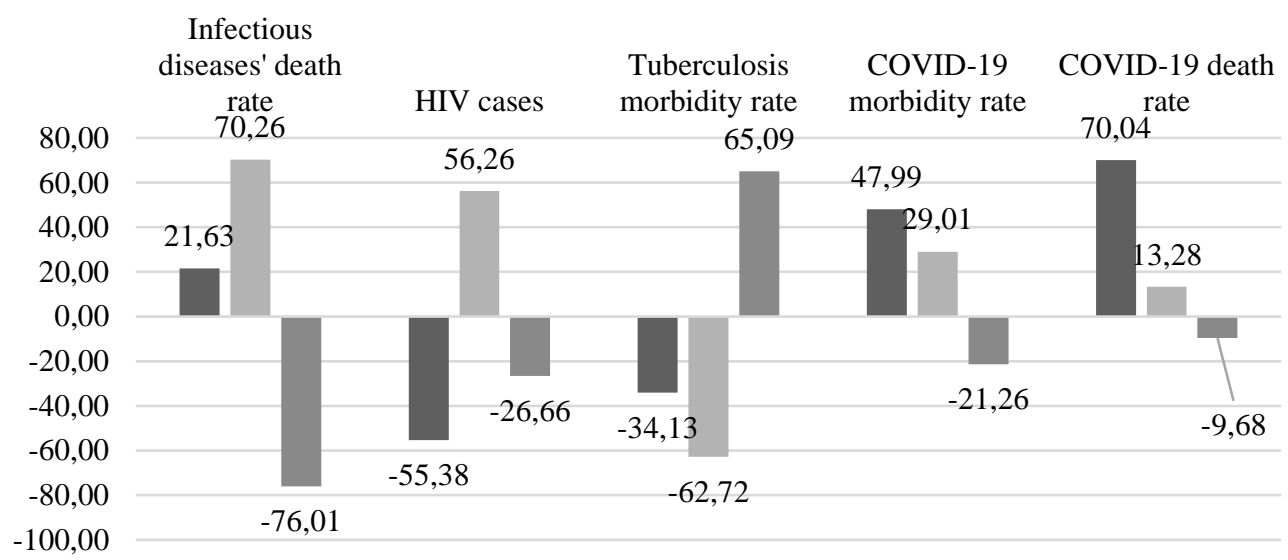

Healthcare expenditures $\square$ Number of medical personnel $\square$ Number of hospital beds

Figure 2. Correlation between quality of fight against the virus threat and the traditional factors in countries with the best results in fight against the virus threat in 2020, \% Source: calculated and compiled by the authors

As is shown in Figure 2, in countries with the best results in fight against the virus threat in 2020 the infectious diseases' death rate is largely determined (decreases in case of increase) by the number of hospital beds (correlation -76.01\%); HIV cases - by expenditures for healthcare $(-55.38 \%)$ and number of hospital beds $(-26.66 \%)$.
Tuberculosis morbidity rate decreases in case of growth of expenditures for healthcare ($34.13 \%)$ and number of medical personnel ($62.72 \%)$. The number of cases and death rate from COVID-19, \% decreases in case of growth of the number of hospital beds ($21.26 \%$ and $-9.68 \%$, accordingly).

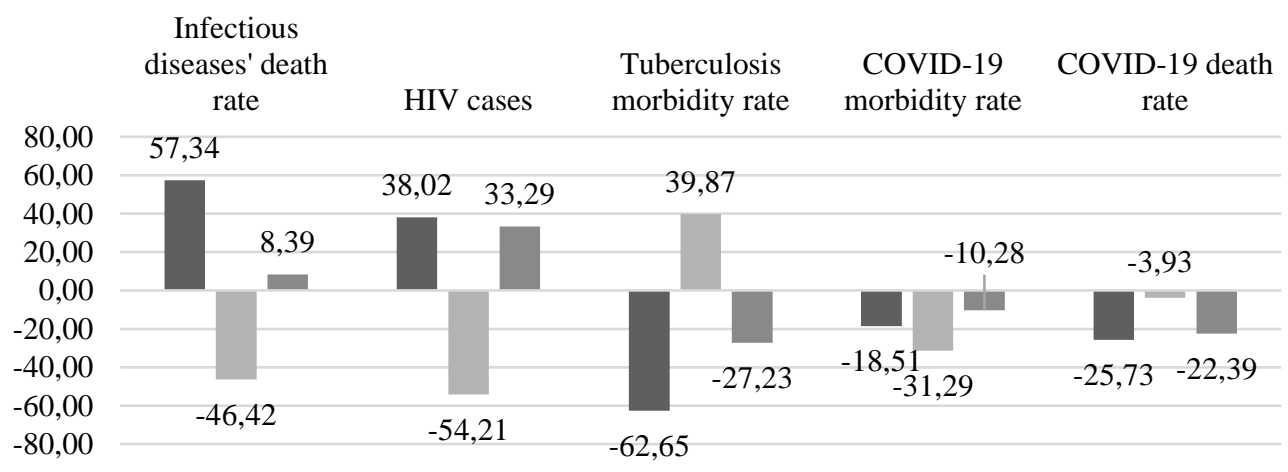

- Level of robotization $\square$ Use of big data and AI $\square$ Development of online public services

Figure 3. Correlation between quality of fight against the virus threat and the factors of industrial and manufacturing engineering in countries with the best results in fight against the virus threat in $2020, \%$

Source: calculated and compiled by the authors 
As shown in Figure 3, in countries with the best results in fight against the virus threat in 2020 , infectious diseases' death rate is largely determined (decreases in case of improvement) by the level of robotization (correlation - 57.34\%); HIV cases - by robotization $(38.02 \%)$ and development of online public services (33.29\%). Tuberculosis morbidity rate decreases in case of growth of the level of use of Big data and AI (39.87\%). The number of cases and death rate from
COVID-19 at the current state of the pandemic ( $2^{\text {nd }}$ trimester) do not depend on the factors of industrial and manufacturing engineering (no positive correlation).

For countyries of the second category, the following results of the correlation analysis of quality of healthcare with the traditional factors (Figure 4 ) and the factors of industrial and manufacturing engineering (Figure 5) are obtained.

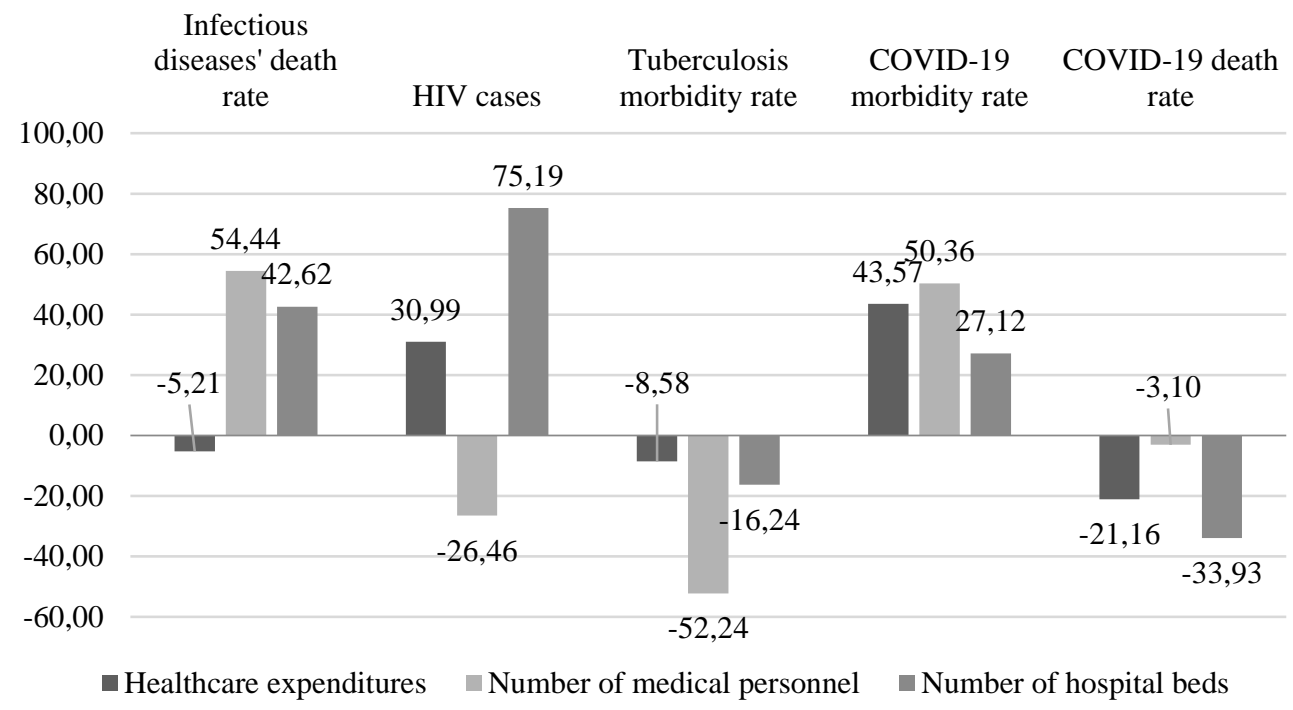

Figure 4. Correlation between quality of fight against the virus threat and the traditional factors in countries with the worst results in fight against the virus threat in $2020, \%$ Source: calculated and compiled by the authors

As shown in Figure 4, in countries that have the best results in fight against the virus threat in 2020, death rate from infectious diseases is largely determined (decreases in case of growth) by expenditures for healthcare (correlation $-5.21 \%$ ); HIV cases - by number of medical personnel $(-26.46 \%)$. Tuberculosis morbidity rate decreases in case of increase of number of medical personnel $(-52.24 \%)$ and number of hospital beds $(-16.24 \%)$. Number of COVID-19 cases does not depend on the traditional factors (no positive correlation). Death rate from COVID-19 decreases in case of growth of expenditures for healthcare $(-21.16 \%)$ and number of hospital beds (-33.93\% and $-9.68 \%$, accordingly). 


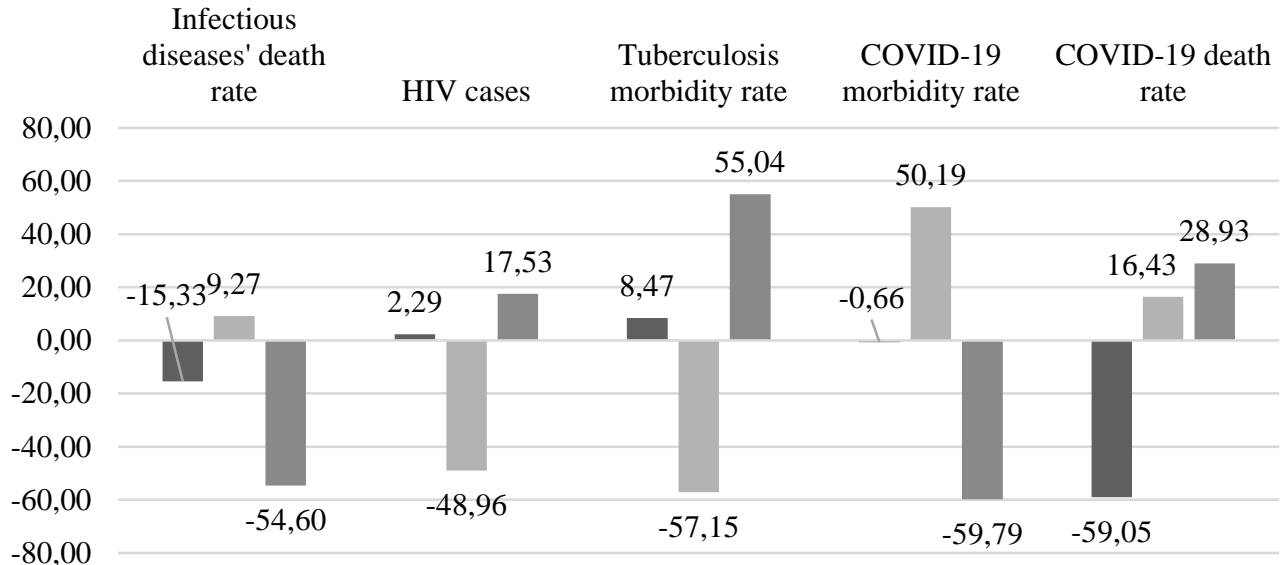

Level of robotization $\square$ Use of big data and AI $\square$ Development of online public services

Figure 5. Correlation between quality of fight against the virus threat and the factors of industrial and manufacturing engineering in countries with the worst results in fight against the virus threat in $2020, \%$

Source: calculated and compiled by the authors

As shown in Figure 5, in countries that have the worst results in fight against the virus threat in 2020, infectious diseases' death rate is largely determined (decreases in case of improvement) by use of Big data and AI (correlation - $9.27 \%$ ); HIV cases - by robotization (2.29\%) and development of online public services (17.53\%). Tuberculosis morbidity rate decreases due to robotization $(8.47 \%)$ and development of online public services (55.04\%). Number of COVID-19 cases decreases due to use of Big data and AI (50.19\%); death rate from COVID-19 decreases due to use of Big data and AI $(16.43 \%)$ and development of online public services (28.93\%).

Average correlation between quality of fight against the virus threat and various factors in countries of the distinguished categories in 2020 is shown in Figure 6.

As shown in Figure 6, in countries that have the best results in fight against the virus threat in 2020 , average correlation equals $-7.16 \%$ with the traditional factors and $5.85 \%$ - with the factor of industrial and manufacturing engineering. In countries that have the worst results in fight against the virus threat in 2020, average correlation is $-8.38 \%$ with the traditional factors and $10.49 \%$ - with the factors of industrial and manufacturing engineering.

Thus, the performed quantitative analysis has shown that the level of digitalization and general progressiveness of the healthcare system largely determines susceptibility of quality of fight against the virus threat to the influence of various factors. In these countries (from the second category), importance of the factors of industrial and manufacturing engineering is much higher as compared to the traditional factors.

In countries with less developed systems of healthcare and lower level of digital competitiveness, the influence of manageability on quality of fight against the virus threat is higher than in countries with well-developed digital economy and progressive system of healthcare. 


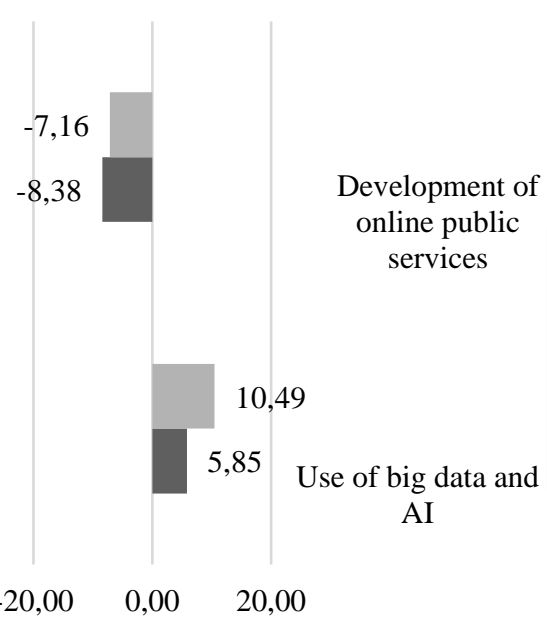

Countries with the worst results in fighting the viral threat in 2020

- Countries with the best results in fighting the viral threat in 2020
Healthcare

expenditures

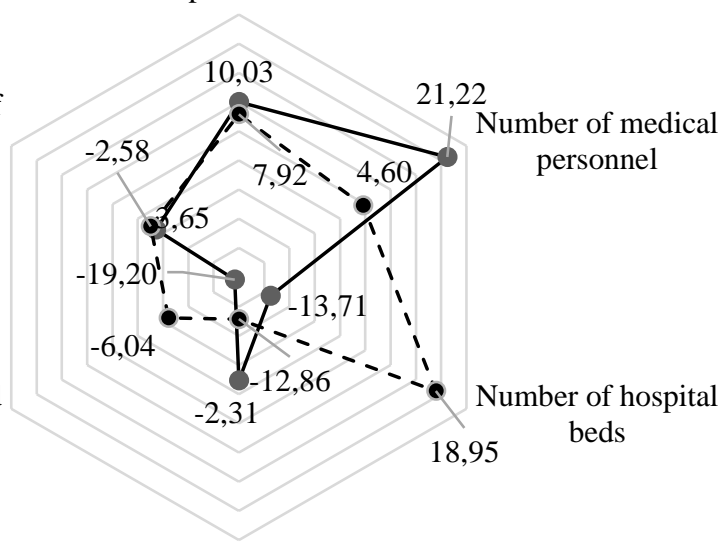

Level of

- Countriesrahatipationst results in fight against the virus threat in 2020

- -0- - Countries with the worst results in fight against the virus threat in 2020

Figure 6. Average correlation between quality of fight against the virus threat and various factors in countries of the distinguished categories in $2020, \%$ Source: calculated and compiled by the authors

\subsection{Qualitative treatment of the advantages of digitalization and Industry 4.0 with the help of industrial and manufacturing engineering for increasing the quality in fight against the virus threat}

Qualitative treatment and expert evaluation of the advantages of digitalization and Industry 4.0 with the help of industrial and manufacturing engineering for increasing the quality in fight against the virus threat in view of its structural components from the positions of game theory are shown in Table 3.

The methodology of game theory (Table 3 ) allows for qualitative and quantitative presentation of the advantages of digitalization and Industry 4.0 for increasing the quality in fight against the virus threat. Precision of measuring the level of virus threat and the developed measures on its prevention is moderately significant (4 points, weight -0.33$)$. The traditional approach (management of the traditional factors) envisages the intuitive character of management and low precision of information and decisions (quality - 2 points out of 5). In case of the digital approach (management of the factors of industrial and manufacturing engineering for development of digital healthcare), Big data and AI guarantee full-scale information and empirical provision and high precision of decision making (quality - 5 points).

Effectiveness of infectious diseases treatment is very significant (5 points, weight -0.42 ). In case of the traditional approach, treatment is complicated, and development of vaccine based on manual labor, with limited possibilities for automatization, is slow (quality - 3 points). In case of the digital approach, robotization and automatization 
ensure hi-tech character of treatment and high speed of development and effectiveness of application of vaccines and drugs (quality - 5 points).

Mass character: quantitative and pricing accessibility of diagnostics and treatment of infectious diseases is least significant (3 points, weight -0.25$)$. In case of the traditional approach, the burden on medical personnel is large, and possibilities of increasing the number of hospital beds are limited (quality - 4 points). In case of the digital approach, remote medical services allow for multiple increase of medical personnel's efficiency (quality - 5 points).

Table 3. Qualitative treatment and expert evaluation of the advantages of digitalization and Industry 4.0 for increasing the quality in fight against the virus threat from the positions of game theory

\begin{tabular}{|c|c|c|c|c|c|c|}
\hline \multirow{2}{*}{$\begin{array}{c}\text { Component of } \\
\text { quality of fight } \\
\text { against the virus } \\
\text { threat } \\
\end{array}$} & \multirow{2}{*}{\begin{tabular}{|c|} 
Significance of \\
the component \\
of quality, \\
points $1-5$
\end{tabular}} & \multirow{2}{*}{$\begin{array}{c}\text { Weight } \\
\text { coefficients of } \\
\text { the component } \\
\text { of quality }\end{array}$} & \multicolumn{2}{|c|}{ Traditional approach } & \multicolumn{2}{|c|}{$\begin{array}{c}\text { Digital approach (Industry } \\
4.0 \text { ) }\end{array}$} \\
\hline & & & Treatment & $\begin{array}{c}\text { Evaluation, } \\
\text { points 1-5 }\end{array}$ & Treatment & \begin{tabular}{|} 
Evaluation, \\
points $1-5$
\end{tabular} \\
\hline $\begin{array}{c}\text { Precision of } \\
\text { measuring the } \\
\text { level of virus } \\
\text { threat and } \\
\text { developed } \\
\text { measures on its } \\
\text { prevention } \\
\end{array}$ & 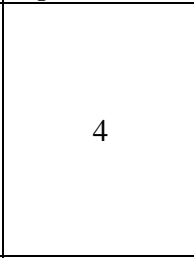 & $4 / 12=0.33$ & $\begin{array}{c}\text { intuitive } \\
\text { character of } \\
\text { management, } \\
\text { low precision }\end{array}$ & 2 & $\begin{array}{c}\text { Big data and AI } \\
\text { guarantee high } \\
\text { precision }\end{array}$ & 5 \\
\hline $\begin{array}{c}\text { Effectiveness of } \\
\text { infectious } \\
\text { diseases } \\
\text { treatment }\end{array}$ & 5 & $5 / 12=0.42$ & $\begin{array}{c}\text { treatment is } \\
\text { difficult, } \\
\text { development } \\
\text { of vaccine is } \\
\text { slow }\end{array}$ & 3 & $\begin{array}{c}\text { robotization and } \\
\text { automatization } \\
\text { ensure hi-tech } \\
\text { character of } \\
\text { treatment }\end{array}$ & 5 \\
\hline $\begin{array}{c}\text { Mass character: } \\
\text { quantitative and } \\
\text { pricing } \\
\text { accessibility of } \\
\text { diagnostics and } \\
\text { treatment of } \\
\text { infectious } \\
\text { diseases }\end{array}$ & 3 & $3 / 12=0.25$ & $\begin{array}{c}\text { burden on } \\
\text { medical } \\
\text { personnel is } \\
\text { high, and } \\
\text { possibilities of } \\
\text { increasing the } \\
\text { number of } \\
\text { hospital beds } \\
\text { are limited }\end{array}$ & 4 & $\begin{array}{c}\text { remote medical } \\
\text { services allow } \\
\text { for multiple } \\
\text { increase of } \\
\text { medical } \\
\text { personnel's } \\
\text { efficiency }\end{array}$ & 5 \\
\hline \multirow{2}{*}{$\begin{array}{c}\text { Quality on the } \\
\text { whole }\end{array}$} & \multirow[b]{2}{*}{$4+5+3=12$} & \multirow{2}{*}{$\begin{array}{c}0.33+0.42+ \\
+0.25=1\end{array}$} & \multicolumn{4}{|c|}{ Hierarchy synthesis } \\
\hline & & & $\begin{array}{r}2 * 0.33+3 \\
* 0.25=0.66+ \\
\end{array}$ & $\begin{array}{l}* .42+4 * \\
1.26+1=2.92\end{array}$ & $\begin{array}{r}5 * 0.33+5 * \\
* 0.25=1.65+2 \\
\end{array}$ & $\begin{array}{l}0.42+5^{*} \\
2.1+1.25=5\end{array}$ \\
\hline
\end{tabular}

Source: developed and compiled by the authors

Thus, according to all components, quality of fight against the virus threat is much higher in the digital approach (hierarchy synthesis: 5 points out of 5) than in the traditional approach (hierarchy synthesis: 2.92 points). This shows the expedience of digitalization of healthcare and development of Industry 4.0 in medicine.

\subsection{Modeling of perspectives and development of recommendations for increasing the quality of fight against the virus threat based on digitalization and Industry 4.0, with the help of industrial and manufacturing engineering}

Substantiation of the advantages of digitalization and use of breakthrough technologies of Industry 4.0 for significant 
increase of quality in fight against the virus threat, which has been provided in this paper, stimulates the specification of the foundations of quality management in healthcare. For obtaining a positive effect in practice, it is necessary to supplement the theoretical substantiation with applied recommendations - i.e., form the policy implications. Development of applied recommendations should be oriented at each determined direction of increasing the quality of fight against the virus threat based on digitalization and Industry 4.0 with the help of industrial and manufacturing engineering.

In the first direction, connected to use of Big data and AI for the healthcare purposes, public benefits are generated recommendations protection of health of wide groups of population. A vivid example of implementation of this direction is adoption of government decrees on selfisolation during the COVID-19 pandemic. Big data and AI allow for determination and quantitative description of the positive effect from self-isolation, determination of its level (in points on the map by the level of traffic), and provision of the optimal variant (rate and sequence) of limitations for social communication and visiting of public places.

As in the case with all public benefits, implementation of this direction does not pose commercial profit and is not interesting for private business. Thus, in view of large social importance of this direction of increasing the quality of fight against the virus threat, it is offered to place a government order for R\&D and to finance the measures on digital modernization of the system of state monitoring and intellectual decision support in healthcare management.

In the second direction, connected to development of the system of online public services in the healthcare system, - i.e., transition to the online form of medical services - the infrastructure is very important. Thus, its intensive development is recommended. Special attention should be paid to the telecommunication infrastructure
- equipping all healthcare establishments (state-funded hospitals, clinics, etc.) with modern digital equipment and Internet. The social infrastructure of digital healthcare is also very important; its development will require support (primarily, by financing and standardization) of training of digital personnel and increase of population's media-literacy.

Within the third direction, which envisages provision of hi-tech medical services MedTech based on automatization (robotization) в healthcare - the perspectives of commercial profit are rather vivid and significant. For example, together with the government (free) COVID-19 vaccine, commercial (paid) vaccine could be developed, which would have more advantages (better immunity, less vivid side effects), as well as drugs and tools for diagnostics and treatment (progressive medical equipment). In order to transfer the financial burden on private business with provision of sufficient control from the government, it is recommended to implement the mechanism of public-private partnership in this direction.

\section{Conclusion}

Thus, it is possible to make the following conclusions. The factors of industrial and manufacturing engineering positively influence the quality in fight against the virus threat - i.e., stimulate its increase: average correlation in countries with a high level of digitalization and progressive system of healthcare equals $5.85 \%$, and in countries with moderate digitalization and less developed system of healthcare - $10.49 \%$ (hypothesis $\mathrm{H}_{2}$ has been proved).

The factors of industrial and manufacturing engineering moderately determine the quality in fight against the virus threat (correlation is below $50 \%$ - hypothesis $\mathrm{H}_{2}$ has been disproved), but they are less significant than the traditional factors, and in countries with moderate digitalization and less developed 
system of healthcare the factors of industrial and manufacturing engineering are even more significant than the traditional factors $(10.49 \%$ vs. $-7.16 \%)$ - i.e., hypothesis $\mathrm{H}_{3}$ has been proved. The factors of industrial and manufacturing engineering determine quality in fight against the virus threat to a larger extent than the traditional factors (correlation between quality of healthcare and the factors of industrial and manufacturing engineering is much higher than with traditional factors).

Contribution of the factors of industrial and manufacturing engineering to increase of quality of services, which are provided in the healthcare system, depends on the level of digitalization of the economic system, which determines the economic system's ability to cope with the virus threat - there are large differences in correlation between countries with different digital competitiveness and successfulness of fight against the virus threat: hypothesis $\mathrm{H}_{4}$ has been proved. Therefore, attention to the issues of development of digital healthcare and management of the factors of industrial and manufacturing engineering should be paid in countries with less developed systems of healthcare and lower digital competitiveness - for obtaining maximum advantages for quality of fight against the virus threat.

The importance of the performed research for development of scientific knowledge consists in provision of the substantiation and practical recommendations for the use of a new - digital - approach to fight against the virus threat. The advantage of the offered approach is the systemic character of managing the factors of quality in healthcare: consideration of not only traditional (financing, number of medical personnel and hospital beds) but also progressive, digital (technological provision, level of automatization) factors. Despite the vivid differences between countries, the new approach is universal and popular around the world - especially in the conditions of the critical virus threat during the COVID-19 pandemic.

Though this research determined the key directions of increasing the quality of fight against the virus threat based on digitalization and Industry 4.0 with the help of managing the factors of industrial and manufacturing engineering, it also showed that actualized new gaps in the scientific thought, which include study of the experience of certain countries (case studies) and development of the applied national models of managing the factors of industrial and manufacturing engineering. They are beyond the limits of this research and should be elaborated in further works on this topic.

Acknowledgment: The research was performed with financial support from the Russian Fund of Fundamental Research within the scientific project No. 18-01000103 A.

\section{References:}

Alpidovskaya, M. L., \& Popkova, E. G. (2019). Marx \& Modernity: A Political \& Economic Analysis of Social Systems Management. A volume in the series Popkova, E.G. (Ed.) Advances in Research on Russian Business \& Management. Charlotte, NC, USA: Information Age Publishing.

Anaba, E. A., \& Abuosi, A. A. (2018). Assessing health care quality in adolescent clinics, implications for quality improvement. International Journal of Health Governance, 23(4), 269-280. https://doi.org/10.1108/IJHG-03-2018-0012

Andersen, K. N., Nielsen, J. A., \& Kim, S. (2019). Use, cost, \& digital divide in online public health care: lessons from Denmark. Transforming Government: People, Process \& Policy, 13(2), 197-211. https://doi.org/10.1108/TG-06-2018-0041 
Baaki, T. K., Baharum, M. R., \& Ali, A. S. (2019). Determining a conceptual framework for safe \& sustainable health-care waste management (SSHCWM) implementation in health-care facilities. Journal of Facilities Management, 17(1), 40-56. https://doi.org/10.1108/JFM-112017-0059

Bäckström, I. (2019). Health-related quality management values - comparing manager \& coworker perceptions. International Journal of Quality \& Service Sciences, 11(4), 588603. https://doi.org/10.1108/IJQSS-08-2018-0071

Bader, Y., \& Ganguli, S. (2019). Analysis of the association between economic growth, environmental quality \& health standards in the Gulf Cooperation Council during 19802012. Management of Environmental Quality, 30(5), 10501071. https://doi.org/10.1108/MEQ-03-2018-0061

Bahadori, M., Teymourzadeh, E., Ravangard, R., \& Saadati, M. (2018). Accreditation effects on health service quality: nurse viewpoints. International Journal of Health Care Quality Assurance, 31(7), 697-703. https://doi.org/10.1108/IJHCQA-07-2017-0126

Candreva, P., \& Eger, R. (2018). Can health benefit outcomes benefit public health budget professionals? Journal of Public Budgeting, Accounting \& Financial Management, 30(1), 4052. https://doi.org/10.1108/JPBAFM-03-2018-005

da Costa, M. P., \& Lima Leite, F. C. (2019). Factors influencing research data communication on Zika virus: a grounded theory. Journal of Documentation, 75(5), 910926. https://doi.org/10.1108/JD-05-2018-0071

Doğu. E. (2012). Monitoring time between medical errors to improve health-care quality. International Journal for Quality research, 6(2), 151-157.

Inshakova, A. O., \& Bogoviz, A. V. (Ed.) (2020). Alternative Methods of Judging Economic Conflicts in the National Positive \& Soft Law. A volume in the series Popkova, E. G. (Ed.) Advances in Research on Russian Business \& Management. Charlotte, NC, USA: Information Age Publishing.

Johanson, D. \& Madsen, D.Ø. (2019). Diffusion of management accounting innovations: a virus perspective. Journal of Accounting \& Organizational Change, 15(4), 513534. https://doi.org/10.1108/JAOC-11-2018-0121

Larasanty, L. P. F., Cahyadi, M. F., Sudarni, N. M. R., \& Wirasuta, I. M. A. G. (2019). Patient satisfaction with pharmaceutical care services provided at primary-level \& secondary-level health facilities in Indonesia's health coverage system. Journal of Health Research, 33(1), 8088. https://doi.org/10.1108/JHR-06-2018-0033

MacVane Phipps, F. (2020). Quality initiatives in public health \& other health-related fields. International Journal of Health Governance, 25(2), 177182. https://doi.org/10.1108/IJHG-04-2020-0026

Markham, W. A. (2019). Good human functioning, health \& the promotion of health. Health Education, 119(5/6), 382-407. https://doi.org/10.1108/HE-08-2019-0036

Nayak, B., Bhattacharyya, S. S., \& Krishnamoorthy, B. (2019). Application of digital technologies in health insurance for social good of bottom of pyramid customers in India. International Journal of Sociology \& Social Policy, 39(9/10), 752772. https://doi.org/10.1108/IJSSP-05-2019-0095

Omar, N. A. S., \& Fen, Y. W. (2018). Recent development of SPR spectroscopy as potential method for diagnosis of dengue virus E-protein. Sensor Review, 38(1), 106116. https://doi.org/10.1108/SR-07-2017-0130 
Piroozi, B., Zarei, B., Ghaderi, B., Safari, H., Moradi, G., Rezaei, S., .., \& MohamadiBolbanabad, A. (2019). Catastrophic health expenditure \& its determinants in households with gastrointestinal cancer patients: evidence from new health system reform in Iran. International Journal of Human Rights in Healthcare, 12(4), 249-257. https://doi.org/10.1108/IJHRH-012019-0008

Platt, J., Raj, M., \& Kardia, S. L. R. (2019). The public's trust \& information brokers in health care, public health \& research. Journal of Health Organization \& Management, 33(7/8), 929948. https://doi.org/10.1108/JHOM-11-2018-0332

Plianbangchang, S. (2018). Health \& disease concepts: an approach to health development. Journal of Health Research, 32(5), 384-386. https://doi.org/10.1108/JHR-082018-045

Popkova, E. G., \& Gulzat, K. (2020a). Technological Revolution in the 21st Century: Digital Society vs. Artificial Intelligence. Lecture Notes in Networks and Systems, 91, 339-345.

Popkova, E. G., \& Sergi, B. S. (2020). Human Capital \& AI in Industry 4.0. Convergence \& Divergence in Social Entrepreneurship in Russia. Journal of Intellectual Capital, https://doi.org/10.1108/JIC-09-2019-0224.

Popkova, E. G., \& Gulzat, K. (2020b). Contradiction of the Digital Economy: Public Well-Being vs. Cyber Threats. Lecture Notes in Networks and Systems, 87, 112-124.

Popkova, E. G., \& Zmiyak, K. V. (2019). Priorities of training of digital personnel for industry 4.0: social competencies vs technical competencies. On the Horizon, 27(3-4), 138-144.

Popkova, E. G. (2017). Economic \& Legal Foundations of Modern Russian Society. A volume in the series Popkova, E.G. (Ed.) Advances in Research on Russian Business \& Management. Charlotte, NC, USA: Information Age Publishing.

Popkova, E. G. (2019). Preconditions of formation and development of industry 4.0 in the conditions of knowledge economy. Studies in Systems, Decision and Control, 169(1), 65-72.

Popkova, E. G., Przhedetsky, Yu V., Przhedetskaya, N. V., \& Borzenko, K. V. (Ed.) (2020). Marketing of Healthcare Organizations: Technologies of Public-Private Partnership. A volume in the series Popkova, E. G. (Ed.) Advances in Research on Russian Business \& Management. Charlotte, NC, USA: Information Age Publishing.

Popkova, E. G., \& Sergi, B. S. (2018). Will Industry 4.0 \& Other Innovations Impact Russia's Development? In Bruno S. Sergi (Ed.) Exploring the Future of Russia's Economy \& Markets: Towards Sustainable Economic Development (pp. 51-68). Bingley, UK: Emerald Publishing Limited.

Popkova, E. G., \& Sergi, B. S. (Eds.) (2019). Digital Economy: Complexity \& Variety vs. Rationality. Berlin, Germany, Springer International Publishing.

Pronovost, P. J., Armstrong, C. M., Demski, R., Peterson, R. R., \& Rothman, P. B. (2018). Next level of board accountability in health care quality. Journal of Health Organization \& Management, 32(1), 2-8. https://doi.org/10.1108/JHOM-09-2017-0238

Ragulina, Y. V. (2019). Priorities of development of industry 4.0 in modern economic systems with different progress in formation of knowledge economy. Studies in Systems, Decision and Control, 169, 167-174.

Rubbio, I., Bruccoleri, M., Pietrosi, A., \& Ragonese, B. (2019). Digital health technology enhances resilient behaviour: evidence from the ward. International Journal of Operations \& Production Management, 40(1), 34-67. https://doi.org/10.1108/IJOPM-02-2018-0057 
Sergi, B. S. (2003). Economic Dynamics in Transitional Economies: The Four-P Governments, the EU Enlargement, \& the Bruxelles Consensus. New York: Routledge.

Sergi, B. S. (Ed.) (2019). Tech, Smart Cities, \& Regional Development in Contemporary Russia. Bingley, UK: Emerald Publishing Limited.

Sergi, B. S., Popkova, E. G., Vovchenko, N., \& Ponomareva, M. (2019a). Central Asia \& China: Financial Development through Cooperation with Russia. In Barnett, William A. \& Bruno S. Sergi (Eds.) Asia-Pacific Contemporary Finance \& Development (International Symposia in Economic Theory \& Econometrics Vol. 26) (pp. 141-164). Bingley, UK: Emerald Publishing Limited.

Sergi, B. S., Popkova, E. G., Borzenko, K. V., \& Przhedetskaya, N. V. (2019b). Public-Private Partnerships as a Mechanism of Financing Sustainable Development. In Ziolo, Magdalena \& Bruno S. Sergi (Eds.) Financing Sustainable Development: Key Challenges \& Prospects (pp. 313-339). London, UK: Palgrave Macmillan,

Stolyarov, N. O., Petrenko, E. S., Serova, O. A., \& Umuralieva, A. S. (2020). The Digital Reality of the Modern Economy: New Actors and New Decision-Making Logic. Lecture Notes in Networks and Systems, 87, 882-888.

Tadić, D., Cvjetković, V., \& Milovanović, D. (2009). Determining \& Monitoring of the Therapy Procedures by Application of the Artificial Intelligence Methods Relevant for Acquiring of the Quality Excellence in the Processes of the Medical Treatment. International Journal for Quality research, 3(3), 1-7.

Thandapani, R. U., Sivasangari, S., \& Haniff, J. (2014). Evolution of medical research registry in a developing country: Malaysia. International Journal for Quality Research, 8(1), 107-120.

Vijay, S. A. (2014). Reducing \& optimizing the cycle time of patients discharge process in a hospital using six sigma dmaic approach. International Journal for Quality Research, 8(2), 169-182.

Young, A. (2018). Digital Health: Critical \& Cross-Disciplinary Perspectives. Journal of Enabling Technologies, 12(4), 198-200. https://doi.org/10.1108/JET-12-2018-059

IMD (2020). World Digital Competitiveness Ranking 2019. Retrieved from: https://www.imd.org/wcc/world-competitiveness-center-rankings/world-digitalcompetitiveness-rankings-2019/ (18.07.2020).

Institute of Scientific Communications (2020). Data set "Epidemics and Pandemics: Big Data for the Scientific Analytics of the Dynamics of Infectious Diseases throughout the World and their Consequences". Retrieved from: https://www.archilab.online/en/data/epidemics-andpandemics (18.07.2020).

Elena G. Popkova

MGIMO University,

Moscow, Russia

elenapopkova@yahoo.com

\section{Aidarbek Giyazov}

Batken State University,

Kyrgyzstan

aziret-81@mail.ru 